\title{
PENTAGONS IN MEDIEVAL ARCHITECTURE
}

\author{
KRISZTINA FEHÉR* - BALÁZS HALMOS** - BRIGITTA SZILÁGYI*** \\ *PhD student. Department of History of Architecture and Monument Preservation, BUTE \\ K II. 82, Müegyetem rkp. 3, H-1111 Budapest, Hungary. E-mail: feher.krisztina@eptort.bme.hu \\ **PhD, assistant professor. Department of History of Architecture and Monument Preservation, BUTE \\ K II. 82, Múegyetem rkp. 3, H-1111 Budapest, Hungary. E-mail: halmos@eptort.bme.hu \\ $* * * \mathrm{PhD}$, associate professor. Department of Geometry, BUTE \\ H. II. 22, Egry József u. 1, H-1111 Budapest, Hungary. E-mail: szilagyi@math.bme.hu
}

\begin{abstract}
Among regular polygons, the pentagon is considered to be barely used in medieval architectural compositions, due to its odd spatial appearance and difficult method of construction. The pentagon, representing the number five has a rich semantic role in Christian symbolism. Even though the proper way of construction was already invented in the Antiquity, there is no evidence of medieval architects having been aware of this knowledge. Contemporary sources only show approximative construction methods. In the Middle Ages the form has been used in architectural elements such as window traceries, towers and apses. As opposed to the general opinion supposing that this polygon has rarely been used, numerous examples bear record that its application can be considered as rather common. Our paper attempts to give an overview of the different methods architects could have used for regular pentagon construction during the Middle Ages, and the ways of applying the form.
\end{abstract}

Keywords: pentagon, medieval, architecture, Gothic, geometry, mathematics

\section{INTRODUCTION}

The example of the Byzantine Greek mathematician Isidore of Miletus who combined his theoretical approach with architectural PRACTICE in the case of Hagia Sophia in Constantinople represents the continuity of the flourishing scientific culture of the Antiquity in the Eastern Roman Empire. During the Migration Period Western Europe has accommodated several new cultures of entirely different conception sweeping away the majority of Greco-Roman knowledge. However, regarding the building activity of the West in the Early Middle Ages, the interaction between mathematics and architecture must have sustained, as the design, tracing and engineering certainly demanded geometrical skills. The examination of the relation between these two disciplines in medieval Europe is of high relevance since the discontinuity of antique science forced architects and craftsmen to invent methods to solve geometrical questions emerging without theoretical background. Arithmetical culture of Early Christian Europe has likely been based on Christian numerology. ${ }^{1}$ In architecture this manifested in numerical proportions, metaphoric dimensions or numbers of elements (columns, windows, etc.) and in case of ground plans as ideal polygons with

\footnotetext{
${ }^{1}$ The great knowledge of numerology could have been cultivated only by the intellectual elite of monasteries. Sódor 1978a 4.
} 
a certain number of sides. The geometrical construction of polygons has thus been a task for architects from the beginning of the Middle Ages. The drawing of simple ones, such as the triangle, square, hexagon or octagon must have always been obvious, the constructions of the figures with an odd number of sides (pentagon, heptagon, nonagon, etc.), however, meant a greater challenge. Studying the example of the problematic pentagon, the correct drafting of which had been forgotten in the Western world since the Antiquity, ${ }^{2}$ the fair number of medieval buildings using it proves that some solutions had always existed. Furthermore, Gothic sources provide evidences that several approximations (resulting a pentagon precise enough to stay within the margin of inaccuracy of the construction) had been figured out.

In the present periodical in 1995 László Hoppe published his significant article about various constructing methods of the pentagon based on medieval sources. ${ }^{3}$ His article is based on an earlier study by Cord Meckseper in a large measure. ${ }^{4}$ Beside Hoppe, János Sedlmayr also mentioned an approximation, namely the one of Hans Hammer, in his study on a tracery window containing a pentagonal element in the Northern wall of Saint Michael's Church of Sopron. ${ }^{5}$ Even the international literature of the case, to be discussed below, is quite scarce, notwithstanding there are several mentions. Hoppe claimed that the medieval application of the pentagon had been rather rare, because of its unfamiliar drafting on the one hand, and on account of the lack of right angles resulting an ambiguous perception of the space on the other. ${ }^{6}$ Sedlmayr suggested that the reason why it has yet appeared in architecture may have been its symbolic meaning or the belief in its protecting role from evil in a church or after all its curiosity. ${ }^{7}$ Concerning the meaning of the number five, one of the many references can be found in the Liber Manualis of the Frankish countess Dhuoda as early as the $9^{\text {th }}$ century: five meant the five clever virgins or the five senses of the body. ${ }^{8}$

Furthermore, other levels of meaning can be mentioned. Five is the number of human need, redemption and grace. Five can refer to the Five Senses, the Five Holy Wounds of Christ, ${ }^{9}$ or to the Wise and Foolish Virgins in a parable of Jesus. ${ }^{10}$ It appears in the 5 curtains, bars and pillars of the Tabernacle, ${ }^{11}$ the altar of which was also 5 cubits long and 5 cubits wide. ${ }^{12}$ Hence it is not a coincidence that we so often

${ }^{2}$ The correct construction of the regular pentagon has been worked out by Hippasus and Euclid. Scriba et el. 2015.41.

${ }^{3}$ Hoppe 1995.

${ }^{4}$ Meckseper 1983.

${ }^{5}$ Sedlmayr 1992.

${ }^{6}$ Hoppe 1995. 141.

${ }^{7}$ Sedlmayr 1992.

${ }^{8}$ In chapter LXVI. Bondurand 1887. 33. In the fifth chapter of the book, Dhuoda explained that the word Deus contains 4 and 5, as the letter $\Delta$ was 4 in Greek (with the meaning of the four elements, the four virtues, the four Evangelists, the four parts of the world), and D was 500 in Latin (with the meaning of the five senses).

${ }^{9}$ John 19:34, John 20:24.

${ }^{10}$ Matthew 25.

${ }^{11}$ Exodus 26.

${ }^{12}$ Exodus 27. 
see the number five in churches. Five, however, is also related to the quinta essentia in alchemy. The pentagram is the symbol of Pythagoreans, and is also related to Golden Ratio.

As mathematics and architecture have always been in close interaction in historical periods, our paper is based on an interdisciplinary research on scholars of architecture and mathematics. We are attempting at a revision of the interpretations of known medieval graphical representations of pentagon constructions analysing the mathematical background of the approximation. We also provide a wider collection of pentagonal architectural examples less cited in the literature. Another important aspect of the topic is how medieval architects used and learnt mathematical knowledge and how they transferred it to each other.

\section{PENTAGONS IN MEDIEVAL SOURCES}

In his article, Hoppe has described and examined all known medieval sources containing pentagonal constructions: a sketch in the Portfolio of Villard de Honnecourt by his descendent master; Matthias Roriczer's Geometria Deutsch; two drawings from the plan collection of Akademie der Bildenden Künste in Vienna; and the sketchbook of Hans Hammer. Besides them Hoppe also provided further methods of pentagon approximation the medieval application of which we have no actual evidences for. ${ }^{13}$ Our paper restricts to the examination of the original medieval drawings and the review of their clues suggested by Hoppe, Meckseper and further international references.

In fact, a didactic, step-by-step method for an approximate drafting of the regular pentagon only exists in the late Gothic book of the Geometria Deutsch ${ }^{14}$ (14861490). This version has also been published by Albrecht Dürer in his Underweysung der Messung (1525). In the $15^{\text {th }}$-century sketchbook of Hans Hammer the pentagonal drawing is void of text but is detailed enough so as all the steps would be clear. The other sources provide mainly rough sketches with less information, so in some cases the contemplation of the construction can be speculative or even mistakable. Thus in most of the cases what Hoppe and Meckseper provided are possible clues for these sketches.

\section{PENTAGONS IN THE PORTFOLIO OF VILLARD DE HONNECOURT}

Carl F. Barnes, the author of the latest critical facsimile of the well-known portfolio of the Picardian master claimed that the pentagonal drawing on folio 21 recto can be dedicated to a person named Hand $I V$, who erased the original drawing of Villard

${ }^{13}$ Hoppe 1995. 154-159.

${ }^{14}$ Commented facsimile by Sódor 1982 . 
from the preceding page and redrew it in the last quarter of the $13^{\text {th }}$ century. ${ }^{15}$ Barnes doubted that this person could have been an architect for some basic misunderstandings on his other copied figures. ${ }^{16}$ The text written below the drawing in question 'par chu portrait om one / toor a chinc arestes ${ }^{17}$ - indicates that its purpose has been the layout for a pentagonal tower. ${ }^{18}$ (Fig. 1) The drawing in fact provides a method for constructing a regular pentagon the steps of which are quite didactic. The clue of the principle and the algorithm of the method have been first suggested by Meckseper, whose opinion was shared by Hoppe as well as by Roland Bechmann: the 3 to 1 ratio provides the approximation of the tangent of $72^{\circ}$, which is the exterior angle of the regular pentagon. ${ }^{19}$ (Fig. 2)

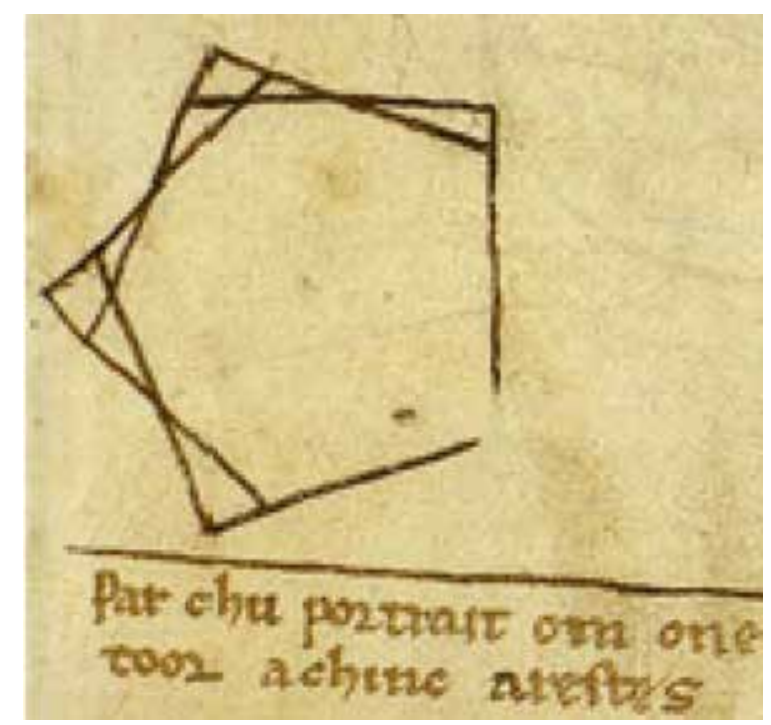

Figure 1. Pentagonal figure in Villard's sketchbook (after folio $21 r$ in Barnes 2009)

The simplicity of this drafting could suggest that it may have been widely known and used in the time of Villard, but this is as obscure as the real purpose of the whole portfolio, as Barnes admitted. ${ }^{20}$ In his opinion the book could have been Villard's own notebook in which he sketched the novelties he observed during his journeys, instead of serving lodge purposes as a model book originally, as earlier scholars believed.

\footnotetext{
${ }^{15}$ Barnes 2009. 13, 147-148.

${ }^{16}$ Barnes 2009. 13.

17 'By this [means] one represents a tower with five edges.' translated by Barnes 2009. 148.

${ }^{18}$ Barnes 2009. 148.

${ }^{19}$ Meckseper 1983; Hoppe 1995. 144-146; Bechmann 1991. 146-148.

${ }^{20}$ Barnes 2009. 23-26.
} 
Barnes was not persuaded of Villard having been a master builder either ${ }^{21}$ but the special point of view and projection of some figures (e.g. plan or elevation drawings or the structural drawings of roofing, etc.) are indicative of an architect's mind. The demand for the representation of a pentagonal tower also affirm this suspicion.
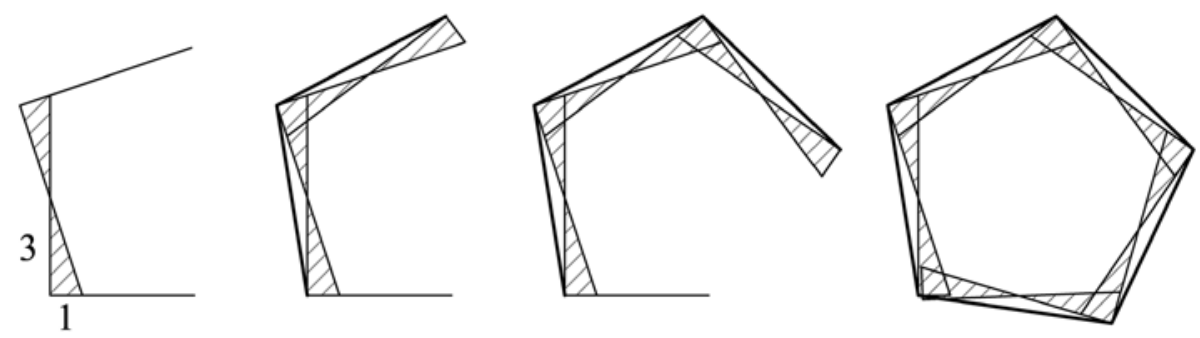

Figure 2. Steps of the pentagon construction from Villard's sketchbook suggested by Meckseper, Bechmann and Hoppe (authors' drawing)

However convincing Meckseper's suggestion for the reconstruction of the steps of the drafting is, other ways of rotating right triangles of legs in 1 to 3 ratio can also be imagined, as discussed in a recent publication of the authors of this paper. ${ }^{22}$

\section{PENTAGON CONSTRUCTION IN MATHIAS RORICZER'S GEOMETRIA DEUTSCH}

Besides Dürer, who also published this drafting, Roriczer's printed booklet from about 1498, titled Geometria Deutsch contains the only pentagonal drawing that has been published with written comments excluding the chance of misunderstandings in modern interpretations. The first facsimile with English translation, of all the works of Roriczer and his lodge-mate Hans Schmuttermayer, was edited by Lon R. Shelby in $1977 .{ }^{23}$ A richly commented Hungarian translation was published by Alajos Sódor in the $14^{\text {th }}$ volume of the present periodical. ${ }^{24}$ Among Roricer's several useful geometrical exercises, the pentagon construction has been cited by Alfred Hiscock, ${ }^{25}$ Meckseper ${ }^{26}$ and Hoppe. ${ }^{27}$ The main advantage of the construction that Roriczer also emphasized is that it could be drawn from the first step to the last using the same opening of the compass.

\footnotetext{
${ }^{21}$ Ibid.

${ }^{22}$ Fehér et al. 2018.

${ }^{23}$ Shalby 1977.

${ }^{24}$ Sódor 1982.

${ }^{25}$ Hiscock 2000. 192-193.

${ }^{26}$ Meckseper 1983. 38.

${ }^{27}$ Hoppe 1995. 145-147.
} 

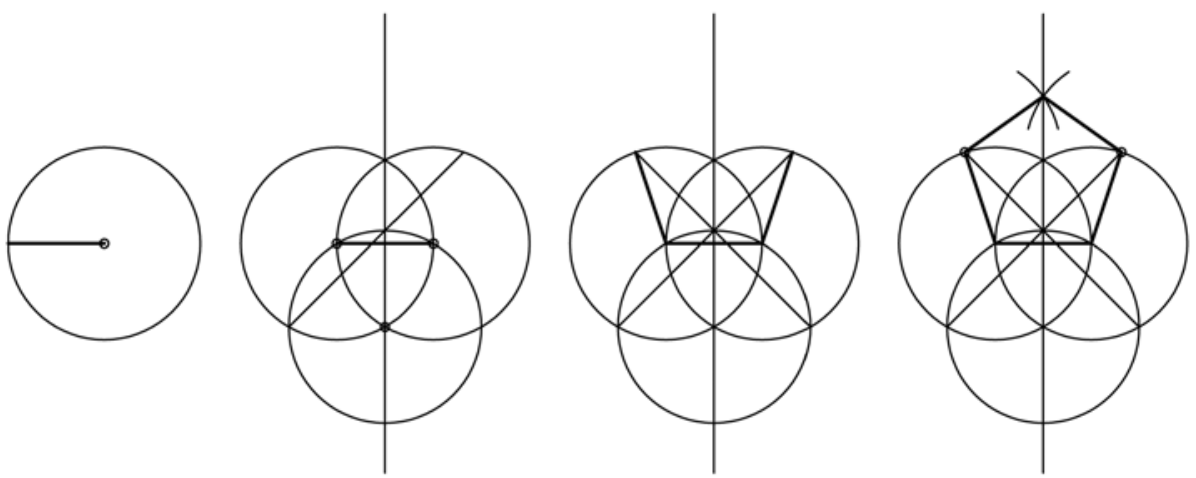

Figure 3. Steps of Roriczer's pentagon construction in Geometria Deutsch (authors' drawing)

However useful this can be for drawing in a smaller scale, and however clear Roriczer's descriptions are, the method itself is far from obvious or easy to memorise. (Fig. 3) Unlike the method in the Portfolio of Villard, where only the simple 1 to 3 proportion was to be recalled, Roriczer's method needs numerous steps lacking an easily memorisable principle. This probably means that there must have been a lodge book or even some text or figure in the master mason's workshop serving as a pattern book. Perhaps, in the case of Geometria Deutsch this was one of the reasons why Roriczer summarised 'from geometry some useful little items' ${ }^{28}$ that among other professionals an architect needed. The complexity of the drafting also raises the question of the transmission of this knowledge from one generation to another. While in the case of Villard's portfolio, nothing is known about either his successors or the further 'Hands', the spread of his pentagon construction method is quite obscure. The Roriczer family, however, was a notable and successful German dynasty of master masons in the late Gothic era. Mathias's father, Konrad Roriczer was the master of the Cathedral of Nürnberg, where his son and maybe Hans Schmuttermayer ${ }^{29}$ worked under his direction. Both Mathias Roriczer ${ }^{30}$ and Schmuttermayer had referred to their mutual predecessors, the 'youngsters of Prague' 31 that had invented new methods of constructions and from whom they had learned this knowledge. Thus, the introduction of both books are highly valuable from the aspect of the transfer of architectural knowledge at the end of the $15^{\text {th }}$ century, particularly because neither Roriczer nor Schmuttermayer had alluded to any secrets to be kept but they had

\footnotetext{
${ }^{28}$ Shalby 1977. 114.

${ }^{29}$ Author of the other late $15^{\text {th }}$-century German lodge book about the construction of the pinnacle and the wimperg. Facsimile by Shalby 1977 and Sódor 1981.

${ }^{30}$ In his Pinnacle book.

${ }^{31}$ Sódor suggested that the connection between the 'youngsters' and the Roriczers could have been Wenzel Roriczer, Konrad's father, who worked with the Parler lodge of the Cathedral of Prague in the second decade of the $15^{\text {th }}$ century. Sódor $1978 \mathrm{~b} 383$.
} 
willingly shared their information for the hopeful advancement of architecture and common weal. Furthermore, these texts provide evidences that the evaluation and education of geometrical drafting methods in this period were certainly characterised by the architects' own inventions matching to their practical demands that could have been learnt by the cooperation of master masons.

On the other hand, Roriczer's acknowledgement in the beginning of his pinnacle book, the Büchlein von der Fialen Gerechtigkeit implies the intellectual background of the publication. He named Wilhelm of Reichenau, bishop of Eichstätt, who, being 'not only the lover and patron of the liberal art of geometry, but also (...) desirous in thought, wish, and intention that those who must use and make a living by it will come to a deep understanding and comprehension of it ${ }^{\prime 32}$ encouraged him to give free run to these methods so that those who apply geometry could access them. ${ }^{33}$ Concerning the transfer of knowledge, it seems that in late Gothic times a lord or an ecclesiastic honour worked out the educational policy of their land and by collecting books and cultivating their knowledge on the liberal arts, they tended to take over the intellectual centre role that monasteries had played before. ${ }^{34}$ This indicates the influence of humanism, the adaption of the Renaissance conception of knowledge and science as a common benefit of mankind adopted by master masons' lodges still working in a flourishing late Gothic style in the $15^{\text {th }}$ and $16^{\text {th }}$ centuries.

The pentagon drafting appearing in the Geometria Deutsch is thus the result of changes in the society and the cultural development of individuals of the medieval bourgeoisie including master masons who could reach knowledge on arithmetic and geometry also outside the walls of universities. As Roriczer admitted he had published the geometrical methods in order to open the possibility of their further development, which eventuated in the Underweysung der Messung of Albrecht Dürer, who also published Roriczer's approximate method along with the presentation of the correct drafting of the regular pentagon that he reinvented without referring to antique sources. ${ }^{35}$

In Hoppe's interpretation the fact that Dürer also presented Roriczer's method means that this method was rather widely known in the Middle Ages, which is quite acceptable. It is also remarkable that one single opening of the compass is used for the whole construction. This could have been an advantage while drawing in a smaller scale and it was for sure a huge benefit while tracing on the construction site as one piece of rope with a stake on both ends was sufficient without any adjusting.

\footnotetext{
${ }^{32}$ Shalby 1977. 83.

${ }^{33}$ Sódor 1978b. 391.

${ }^{34}$ De Jonge 2014.

${ }^{35}$ The correct drafting method of the regular pentagon was known in the Antiquity but it was forgotten during the Middle Ages. Scriba et al. 2015. 249, 292, 323.
} 


\section{PENTAGONAL FIGURES IN THE PLAN COLLECTION OF VIENNA}

The two Vienna pentagons that Hoppe has described ${ }^{36}$ can be found in the sheets of no. $16963^{37}$ and no. $17079^{38}$ of the Collection of Prints and Drawings of the Vienna Academy of Fine Arts. ${ }^{39}$ As neither of these drawings are precisely constructed with blind lines or any didactic help, the suggestions that Hoppe and formerly Meckseper have provided are hypothetic clues for their interpretation. The steps figured out by Meckseper for the figure on sheet no. 17079 are certainly logical, though the whole drafting is much more complicated than assumable by the amount of lines in the drawing. (Fig. 4) The logic behind the method is quite clear: it approximates the quasi-regular pentagon from up and below, searching the proper angle of the upper edge between an acute and an obtuse one.
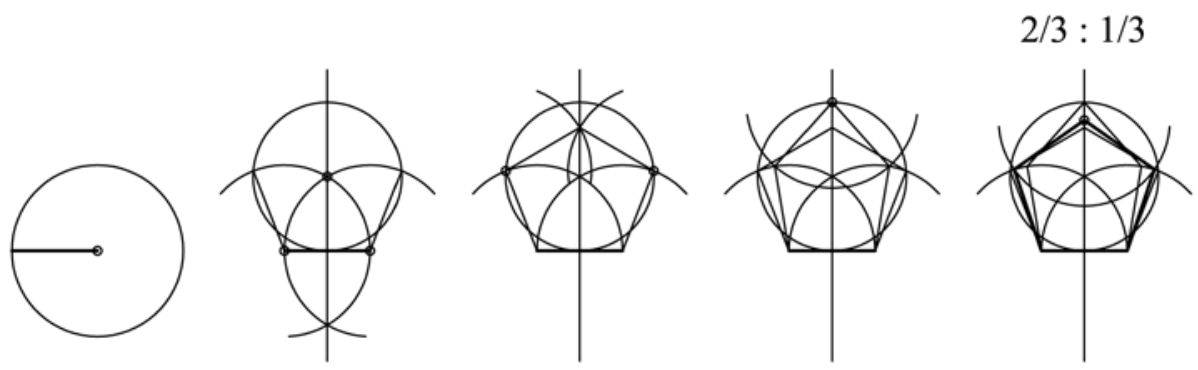

Figure 4. Steps of the reconstruction of the pentagon construction from sheet no. 17079 suggested by Meckseper (authors' drawing)

The solution Hoppe proposed for the idea of the other drawing of no. 16963 is rather disputable similarly to the other one.

The most recent publication of the Gothic drawings of Vienna by Johann Josef Böker also lists another drawing as an approximate construction of the pentagon. ${ }^{40}$ This rather enigmatic drafting on sheet no. 16935 verso, however, does not show an actual pentagon. Böker gives a quite detailed explanation of his interpretation and also provides the graphical explanation of the suggestion. ${ }^{41}$ While the explanation is quite remarkable, the original drawing itself does not show an actual pentagon, and also the context in which it is located on the sheet makes this interpretation rather disputable.

\footnotetext{
${ }^{36}$ Hoppe 1995. 146-149, 153-155.

${ }^{37}$ Fig. 148 by Koepf 1969.

${ }^{38}$ Fig. 264 by Koepf 1969.

${ }^{39}$ The first facsimile of the Gothic collection was published by Koepf 1969, and the latest one by Böker 2005.

${ }^{40}$ Böker 2005. 395.

${ }^{41}$ It is remarkable that this drawing attributed to Dominic Boulerice is the only explanative illustration in the whole publication.
} 


\section{PENTAGON DRAFTING IN HANS HAMMER'S SKETCHBOOK}

The sketchbook of Hans Hammer (Hans Meiger von Werde) dating from the last tierce of the $15^{\text {th }}$ century has several similarities with Villard's portfolio concerning for instance their colourful subjects of drawings, as well as the uncertainty of the purpose of their work. It is also worth mentioning that both masters visited Hungary during their journeys. ${ }^{42}$ Like in the case of Villard, Hans Hammers book is likely to be a collection of the master's own sketches of the wide interest of a Gothic architect. The Strasburg master however, unlike Villard, has noted some data of his biography in his book, which provides information on the period when his pentagonal construction could have been applied..$^{43}$ The geometrical drafting has been cited by Sedlmayer as a possible method used for the design of a tracery window in Saint Michael's Church of Sopron ${ }^{44}$, and Hoppe has also reconstructed the steps of the method with the description of its arithmetic background ${ }^{45}$ Although Hans Hammer left no description to the figure, the steps are as obvious as those of the Geometria Deutsch, but while Roriczer's method is rather complicated, Hans Hammer's one is much easier to memorise. The principle has been the division of the circumcircle to five parts applying a twine of the length of 5/4 of the radius. (Fig. 5) This method actually applies the approximation of $\pi$ as $25 / 8$, which has already been used in ancient Babilonia ${ }^{46}$ Like in the case of Villard's portfolio, the simplicity of Hans Hammers's approximation could facilitate its widespread use, even though no further example or evidence is known for its application so far.
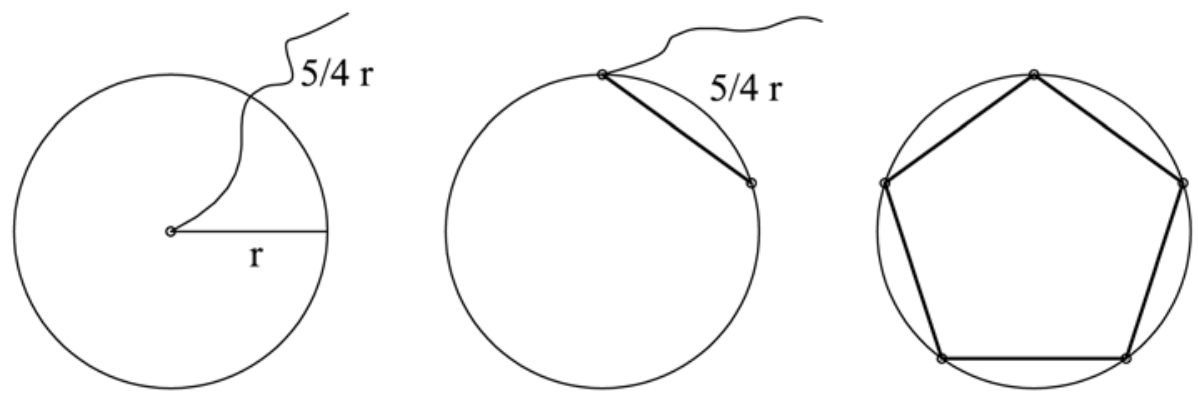

Figure 5. Hans Hammer's pentagon construction (authors' drawing)

${ }^{42}$ Hans Hammer travelled to Hungary between 1478 and 1481. Although the goal of his journay is obscure, the Hungarian-German glossary of architectural terms in his book is of great value. Entz 1992. 9.

${ }^{43}$ The biographical data was summerised by Entz 1992 and a facsimile has been published by Fuchs 1992.

${ }^{44}$ Sedlmayr 1992. 21-22.

${ }^{45}$ Hoppe 1995. 150-153.

${ }^{46}$ Borwein et al. 1997. 1-14. 


\section{PENTAGON OF MASTER WG}

The most peculiar example of pentagonal drawings is certainly the one in the Frankfurt Lodge Book of Master WG created in or around Munich between 1560 and $1572 .{ }^{47}$ (Fig. 6) The meaning and purpose of the drawing on folio 18 of the book is as curious as the very late date for the birth of this book of a certainly Gothic mind. By the opinion of the author of the noted facsimile, François Bucher, Master WG has created his drawings and cut-out figures of rib vaults with nostalgia decades after the dusk of Gothic and the edition of the most important Renaissance treatises. ${ }^{48}$ The accuracy and refinement of the figures are less sophisticated compared to Roriczer's or Villard's work for instance, and their educational purpose is also negligible. Having examined the manuscript in person Bucher claimed that the drawings were based on formerly existing sketches and contained several blind lines scratched with
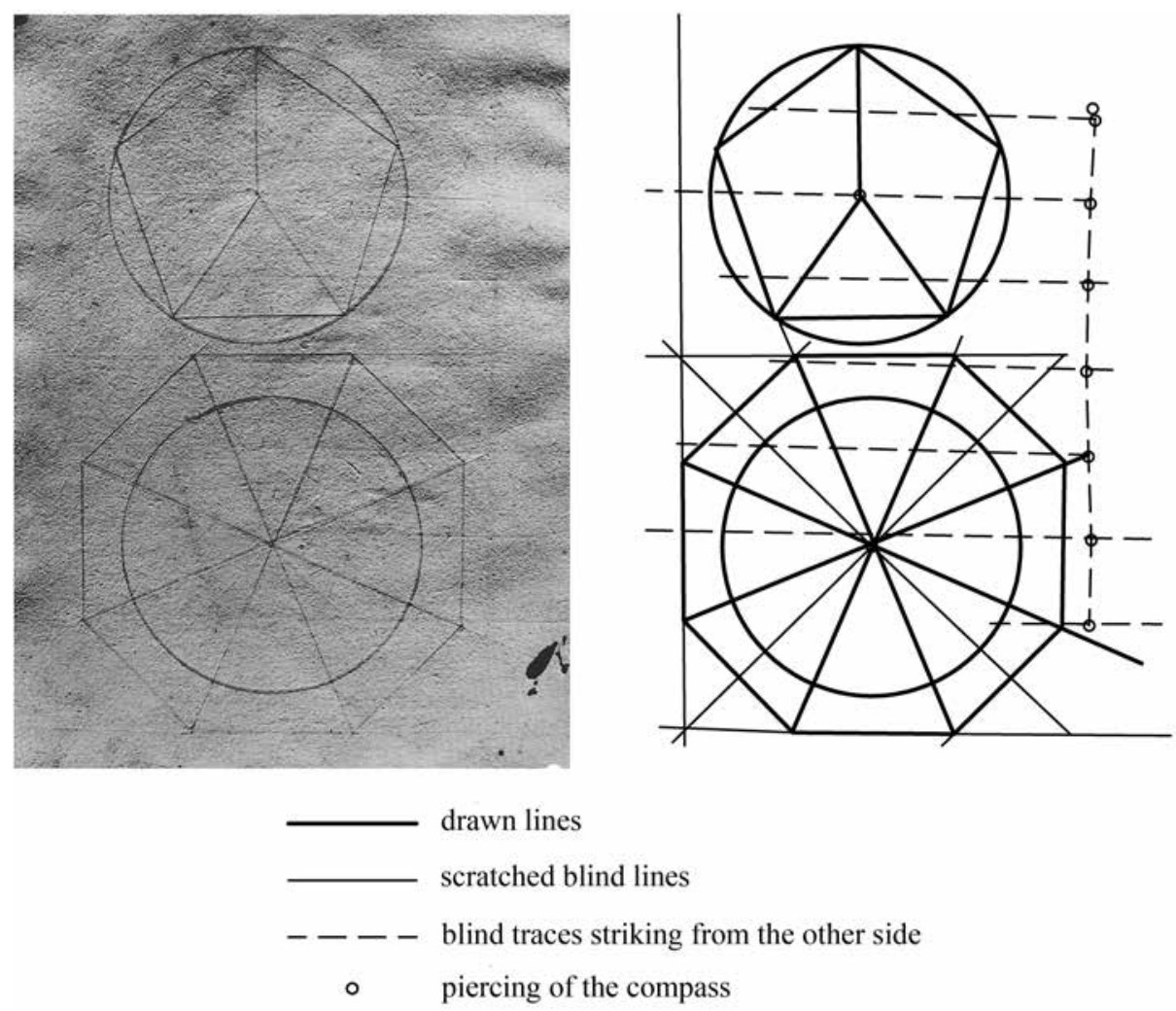

Figure 6. Pentagonal figure in the Frankfurt Lodge Book of Master WG with redrawing of the blind lines (after Bucher 1979. 219; authors' drawing)

\footnotetext{
${ }^{47}$ Bucher 1979. 195-373. By the watermarks the papermill can be localised to Munich.

${ }^{48}$ Bucher 1979. 196-199.
} 

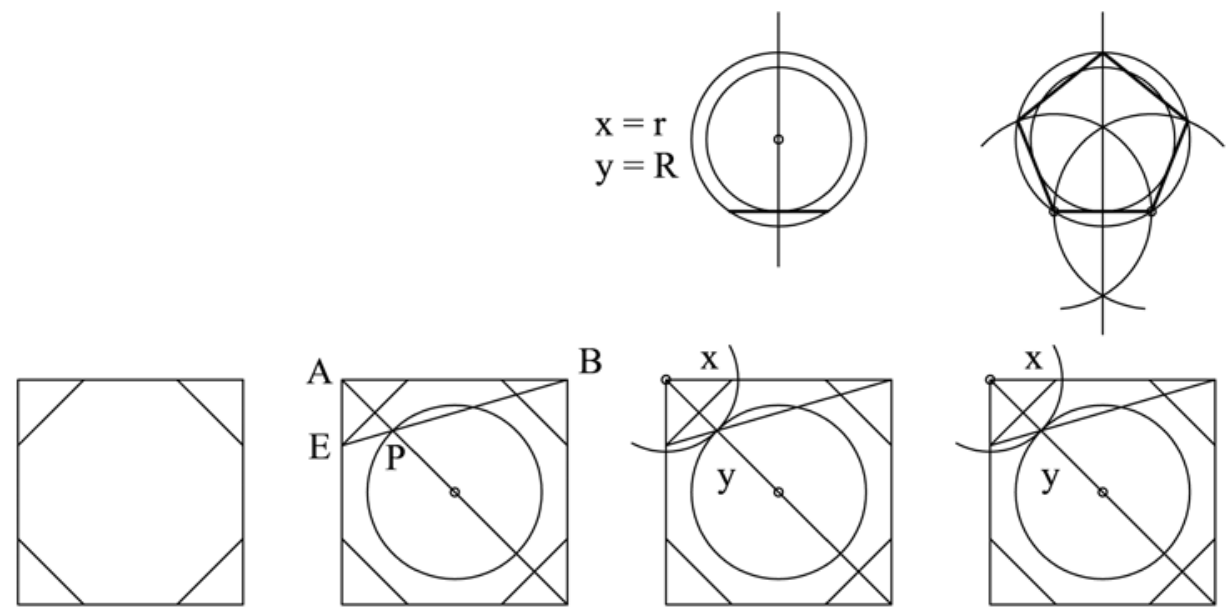

Figure 7. Hoppe's suggestion for the reconstruction of the steps of Master WG's pentagon construction (authors' drawing)
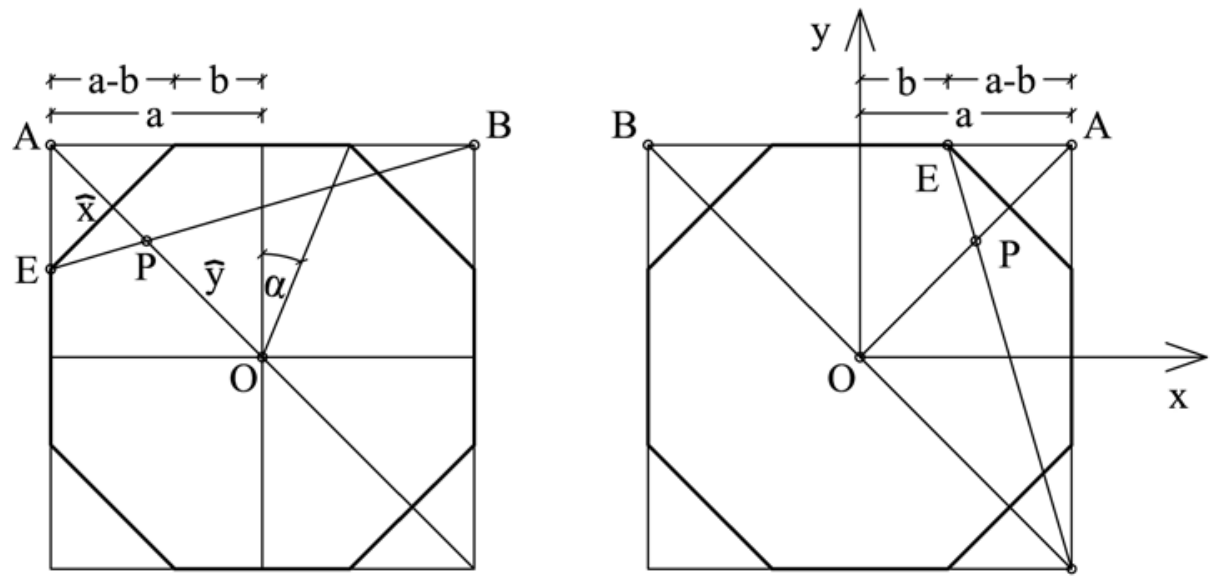

Figure 8. Octagon in the lodge book of Master WG (authors' drawing)

iron or bronze stylus. ${ }^{49}$ These blind lines could provide some narrow chance to understand Master WG's figure in question showing a pentagon with its circumcircle and right below that an octagon with a circle inside. (Fig. 6) Hoppe considered this page of the book a kind of pentagon constructional method that used the octagon and the circle inside to create the radius of the circumcircle ( $y$ in Fig. 7-8) and the circle inscribed ( $x$ in Fig. 7-8) of the pentagon..$^{50}$ (Fig. 7) Although his suggestion is cer-

${ }^{49}$ Bucher 1979. 196.

${ }^{50}$ Hoppe 1995. 148-151. 
tainly remarkable, the system of blind traces barely support his clue as he did not use all of them in his speculated steps, indeed the most crucial line he used for the verification of his theory - that would sever the diagonal of the octagon into the two radii (section EB in Fig. 7-8) - cannot be identified in the original paper at all. (Fig. 6) Furthermore, the distortion of the resulted pentagon is much bigger than in the case of any other approximations. By the arithmetic analysis of Hoppe's suggestion, the mathematical reasons for its unlikelihood can be verified.

In the octagon of Fig. 8 lets determine the ratio of the section $\hat{x}$ and $\hat{y}$.

$$
\begin{gathered}
\alpha=22.5^{\circ} \\
A B=2 a \\
O A=a \sqrt{2} \\
b=a \tan \alpha=a \tan 22.5^{\circ} \\
E(b ; a) \\
B(a ;-a) \\
\overrightarrow{E B}(a-b ;-2 a) \\
n(2 a ; a-b) \\
2 a(x-a)+(a-b)(y+a)=0 \\
P\left\{\begin{array}{c}
2 a(x-a)+(a-b)(y+a)=0 \\
y=x \\
\frac{a^{2}+a b}{3 a+b}=\frac{a^{2}+a^{2} \tan \alpha}{3 a+a \tan \alpha}=\frac{a(1+\tan \alpha)}{3 a+b}=\frac{a(\sin \alpha+\cos \alpha)}{3 \cos \alpha+\sin \alpha}
\end{array}\right.
\end{gathered}
$$

The ratio of the radius of the circumcircle and the inscribed circle of the pentagon is

$$
\begin{gathered}
\hat{x}=x \sqrt{2} \\
\hat{y}=a \sqrt{2}-\hat{x} \\
\frac{\hat{y}}{\hat{x}}=\frac{a \sqrt{2}}{\hat{x}}-1=\frac{a-x}{x}=\frac{a}{x}-1 \\
2 \alpha=45^{\circ}=\frac{\pi}{8}
\end{gathered}
$$




$$
\begin{gathered}
\hat{y} \hat{x}=\frac{(3 \cos \alpha-\sin \alpha)}{\cos \alpha+\sin \alpha}-1= \\
=\frac{(3 \cos \alpha-\sin \alpha)(\cos \alpha-\sin \alpha)}{(\cos \alpha+\sin \alpha)(\cos \alpha-\sin \alpha)}-1= \\
=\frac{\left[2 \cos ^{2} \alpha-4 \cos \alpha \sin \alpha+\left(\cos ^{2} \alpha+\sin ^{2} \alpha\right)\right]}{\cos ^{2} \alpha-\sin ^{2} \alpha}-1= \\
=\frac{\left(2 \cos ^{2} \alpha-2 \sin ^{2} \alpha+1\right)}{\cos 2 \alpha}-1= \\
=\frac{\left(2 \cos ^{2} \alpha-\sqrt{2}+1\right)}{\sqrt{2} / 2}-1= \\
=\sqrt{2}\left(2 \cos ^{2} \alpha-\sqrt{2}+1\right)-1= \\
\approx 0.8284 \\
\frac{\hat{y}}{\hat{x}}=2 \sqrt{2} \cos ^{2} \frac{\pi}{8}-3+\sqrt{2} .
\end{gathered}
$$

While the ratio of the radius of the circumcircle and the inscribed circle of regular pentagon is:

$$
\cos 36^{\circ}=\cos \frac{\pi}{5} \approx 0.8090
$$

The approximation of $36^{\circ}$ from the equation above is $34.062^{\circ}$ that is quite inaccurate.

Nevertheless it is also questionable if the two polygons of the page had any logical connection at all. On the one hand, the blind lines constitute a seemingly coherent system $^{51}$ that embraces the octagon as well as the pentagon. On the other, hand however, except for the frame rectangle, the added lines or the proportion of dimensions do not match at all. (Fig. 6) Even the purpose of the drawing is uncertain, it is not sure at all if Master WG wanted to present a geometrical drafting method for the pentagon.

\section{OTHER SPECULATIVE METHODS}

Without any hint of their medieval application Hoppe added some further modern speculations for the construction of the pentagon. ${ }^{52}$ Except for one - mentioned by

${ }^{51}$ The majority of the blind lines, however, are traces striked from the other side of the same sheet (Fig. 5).

${ }^{52}$ Hoppe 1995. 154-161. 
Alajos Sódor as a current method used by stone carvers of the $20^{\text {th }}$ century - all of these draftings apply some numeric proportions. The method published by Herwig Spiess applied the 10:17 as the ratio of the shorter leg and the hypotenuse of a right triangle providing a quite good approximation of $\cos 54^{\circ}{ }^{\circ 3}$ Hoppe also mentioned two solutions for the application of the Golden Ratio, namely the proportion of 5:8 or 8:13 for the construction of the side of the pentagon from the radius of the circumcircle. ${ }^{54}$

The Golden Ratio also appears in a further possible method of drafting that has been mentioned by Nigel Hiscock ${ }^{55}$ and Tomás Gil-López ${ }^{56}$ as a simple way of translating the design to the site. As a principle the golden triangle (an isosceles triangle whose base and leg are in Golden Ratio) could have been used for the definition of a $72^{\circ}$ angle. (Fig. 9) In fact Villard de Honnecourt used a similar logic in the first half of the $13^{\text {th }}$ century, as he also approximated the $\tan 72^{\circ}$ with a pair of numbers. Golden Ratio (Sectio Aurea) and the method of the golden division of a section had already been known in the ancient times, ${ }^{57}$ and the sequence that Leonardo di Pisa (Fibonacci) has published in his work Liber Abaci, had already been worked out earlier in the Ancient Hindu Pingala's Chandahśs āstra around 200 BC, and the first known written documentation of the sequence is also fifty years older than Liber Abaci (Acharya Hemachandra's Chandonushasana around 1150). ${ }^{58}$ It is undoubtable that the spread of the sequence in Europe in the High Middle Ages was due to Fibonacci. However, neither the direct application of the Fibonacci numbers, nor the use of the Golden Ratio can be surely detected in European architecture before the Renaissance.
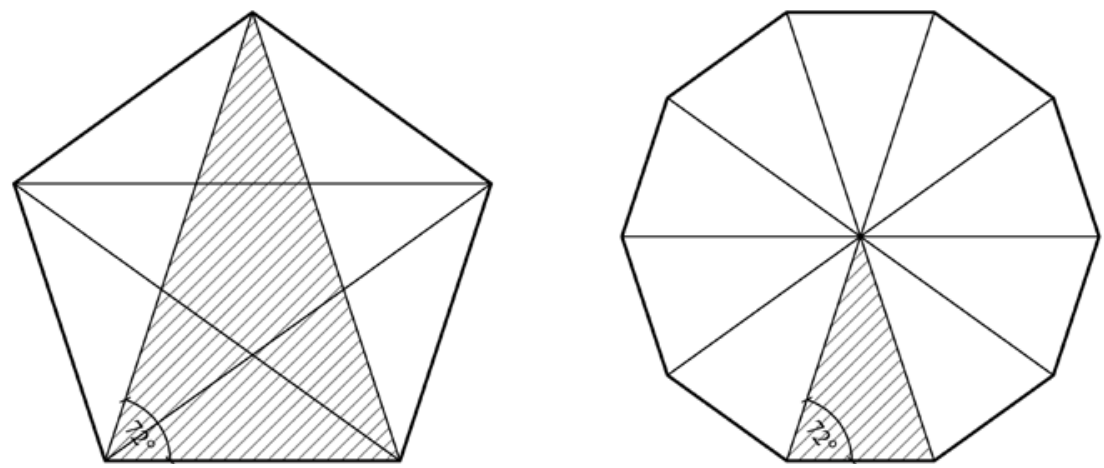

Figure 9. Right triangles in the regular pentagon and the regular decagon (authors' drawing)

\footnotetext{
${ }^{53}$ Spiess 1959. 30-36.

${ }^{54}$ Fehér et al. 2018. manuscript under review

${ }^{55}$ Hiscock 2000. 193, Plate 14.

${ }^{56}$ Gil-López 2012. 178.

${ }^{57}$ Devlin 2012.

${ }^{58}$ Goonatilake 1998. 126.
} 
Last but not least a further numeric proportion should be mentioned that have been published by Hiscock ${ }^{59}$ and applied by Mihály Nagy for the reconstruction of the obscure design method of the cella septichora burial chamber of Sophianae (Pécs, Hungary) in Early Christian Pannonia. ${ }^{60}$ The drafting was based on the section of 11:8 that approximates $\tan 54^{\circ}$, which manifested the same logic proposed by Spiess.

\section{ARCHITECTURAL EXAMPLES OF THE PENTAGON}

Regarding that its geometrical construction has hardly been obvious during all the centuries of the Middle Ages, the architectural application of the pentagon can be considered as rare and special. According to Hoppe's opinion, besides its problematic drafting, the reason why this figure has been rather avoided is the uncomfortable sense of the pentagonal space for lack of any parallels and right angles. ${ }^{61}$ On the other hand, the amount of examples to be described below concludes that pentagon has by no means been ignored or neglected concerning either in floor plan design or detail compositions. Furthermore, its relatively common use, for instance in the design of gothic apses shows that medieval architects surely have been aware of one of its various geometrical constructing methods.

The following series of examples from a wide range of European Christian architecture from the early Middle Ages to the late Gothic, based on several bibliographical and topographical sources ${ }^{62}$ shows that the use of the pentagon was rather general. The examination of this representative amount of buildings is to raise questions of the reasons, aspects and mathematical background knowledge of the application of the pentagon.

These examples can be classified into three main distinct groups demanding different analysis and considerations. The first group embraces buildings with a central plan of a pentagon or a decagon, which are mainly memorial churches, church towers or standalone objects. Although in most of the cases no precisely measured survey is available, the polygon of their plan can be considered ideally regular. Examples of this kind are fairly rare indeed, only a few can be detected sporadically. The second group consists of churches of pentagonal, more precisely half-decagonal apses where the semi-circle of the sanctuary has been divided into five parts. Unlike the first group, these examples are rather common in both space and time of medieval Europe. Finally, the third kind of pentagonal examples are tracery windows, representing a group of an entirely different architectural problem. They are obviously most common in Gothic architecture, however, some rare Romanesque foiled windows of five or ten parts can also be noticed.

\footnotetext{
${ }^{59}$ Hiscock 2000. 281.

${ }^{60}$ Nagy 2002. 28-29.

${ }^{61}$ Hoppe 1995. 141.

${ }^{62}$ Guzsik 1994; Gervers-Molnár 1972; Toman et al. 2000; Christe et al. 1994.
} 


\section{PENTAGONAL AND DECAGONAL ROTUNDAS AND TOWERS}

The above described pentagonal sketch in folio 21 recto of the Portfolio of Villard de Honnecourt proves that the design of a 'toor a chinc arestes' ('a tower with five edges.') ${ }^{63}$ has been an architectural exercise as important as all the problematics from folio $20 r$ to folio $21 r$, such as the determination of the diameter of a partly concealed column ${ }^{64}$ or the cutting of regular or oblique voussoirs and key stones ${ }^{65}$ Commenting the figure in question, Hans Hahnloser claimed that polygonal towers first appeared at the end of $13^{\text {th }}$ century. ${ }^{66}$

Regarding the character of the collected examples, Hahnloser's theory cannot be confuted. All our detected stereometric pentagonal objects are from the centuries of Gothic and they are as rare as decagonal buildings of Romanesque or Early Christian architecture. Interestingly, besides chevets of churches, that are to be described in details in the following chapter, and the exceptional example of the chapter house of Lincoln and Worchester Cathedrals, ${ }^{67}$ no decagonal Gothic buildings can be mentioned. However, the demand of the decagonal shape, and naturally its geometrical construction seems to have always been present in Christian architecture. Although our oldest example of a central space of ten sides is not regular as its plan has an oval shape, it may be considered as a proof of the symbolic importance of the number ten. It is the rotunda of Saint Gereon's Basilica in Cologne dating back to the $4^{\text {th }}$ century. (Fig. 10) Though the church partially collapsed in the Second World War, the reconstruction of the building shows its medieval shape with the Romanesque rotunda erected on the original oval plan with ten axes and eight circular bays, covered by a $13^{\text {th }}$-century vaulting of ten parts. ${ }^{68}$
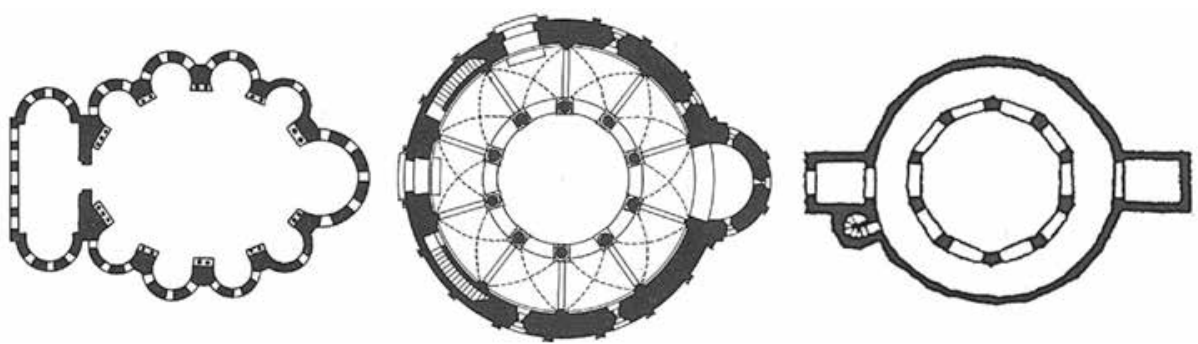

Figure 10. Plan of Saint Gereon's Basilica in Cologne, the rotunda of San Lorenzo in Mantua and Saint Walpurga in Groningen (after Christe et al. 1994. 108, 320; Gervers-Molnár 1972. 17)

\footnotetext{
${ }^{63}$ Translated by Barnes 2009. 148.

${ }^{64}$ Barnes 2009. 131.

${ }^{65}$ Barnes 2009. 133, 137, 141-143.

${ }^{66}$ Hahnloser 1972. 124.

${ }^{67}$ Hiscock 2000. 192-193; Christe et al. 1994. 409.

${ }^{68}$ Guzsik 1994. II. 70-71.
} 


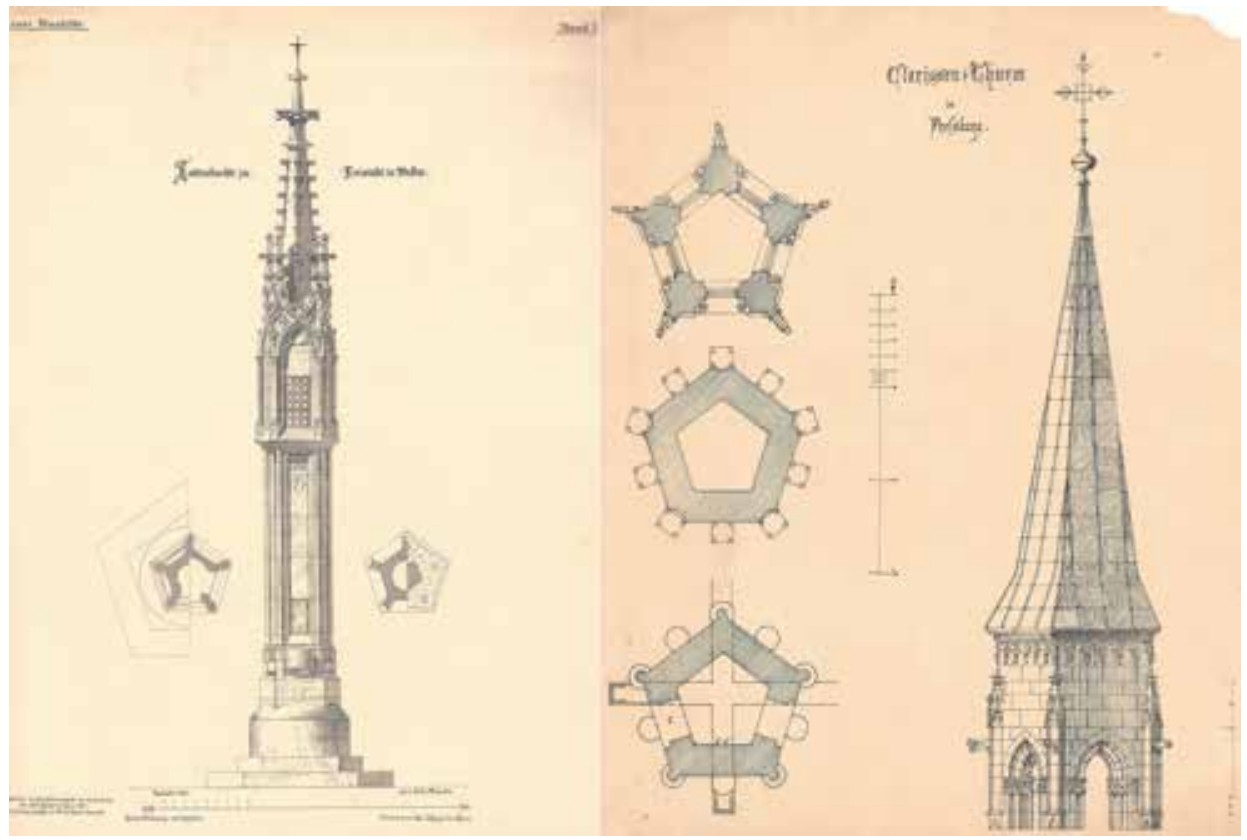

Figure 11. 'Pillars of light' in the Saint Mary's Church in Freistadt and the tower of the Clarissine Church in Bratislava (Wiener Bauhütte vol. XVI; Plan Collection no. 101161)

The Mausoleum of Theoderic the Great in Ravenna proves that the geometrical construction of the quasi regular decagon must have been known in Western Europe in the $6^{\text {th }}$ century. The rotunda of Saint Walpurga in Groningen (the Netherlands) from around 900 (Fig. 10), ${ }^{69}$ the rotunda of San Lorenzo in Mantua from 1083 (Fig. 10), ${ }^{70}$ and two examples from the $12^{\text {th }}$ century, the decagonal castle chapel of Vianden (Luxemburg) $)^{71}$ and the rotunda of Senones (Il-de-France) ${ }^{72}$ also represent the unique and isolated appearance of the figure.

In all these examples including the above-mentioned chapter house of Worchester Cathedral from the early $12^{\text {th }}$ century and Lincoln Cathedral from the $13^{\text {th }}$ century ${ }^{73}$ the decagonal shape defines the interior space of the buildings, even in the case of the two-story Vianden castle chapel where the hexagon of the inner arcades and the decagon of the ambulatory produce a unique character of space.

It was in the Gothic period when real pentagonal buildings first appeared. In each case the perception of space is secondary, the appearance of the mass of these con-

${ }^{69}$ Gervers-Molnár 1972. 17.

${ }^{70}$ Christe et al. 1994. 320.

${ }^{71}$ Guzsik 1994. II. 113.

${ }^{72}$ Guzsik 1994. II. 111.

${ }^{73}$ Hiscock 2000. 192-193; Christe et al. 1994. 409. 
structions is more significant. Thus, in accordance with Hoppe, the pentagon has hardly been used as a shape of space that was to be experienced from inside, but mainly as a construction prevailing from the outside. ${ }^{74}$ Therefore, each example, all originating from the $15^{\text {th }}$ century, is a subsidiary construction joining to primary structures. As a standalone pentagonal object the unique example of the lantern of the dead or 'pillars of light' in the Saint Mary's Church in Freistadt from 1484 is to be cited. (Fig. 11) Hoppe has drawn the attention to the pentagonal staircase tower of the upper level of Martinsturm of Basel Cathedral probably constructed by Hans Hammer who worked in the town at the same time. ${ }^{75} \mathrm{He}$ also mentioned the curious tower of the Clarissine Church in Bratislava that was built as an addition to the former $14^{\text {th }}$-century western façade. ${ }^{76}$ (Fig. 11) A pentagonal baldachin appended to a pillar can be found in the Church of the Holy Spirit in Landshut from 1461. (Fig. 11)

Regarding that all pentagonal objects date back to the $15^{\text {th }}$ century and no similar examples can be noticed from earlier times, the early appearance of the $13^{\text {th }}$-century figure of Hand $I V$ in the portfolio of Villard raises the question of its relation with real buildings. Even though the comment of the author himself suggests it can be

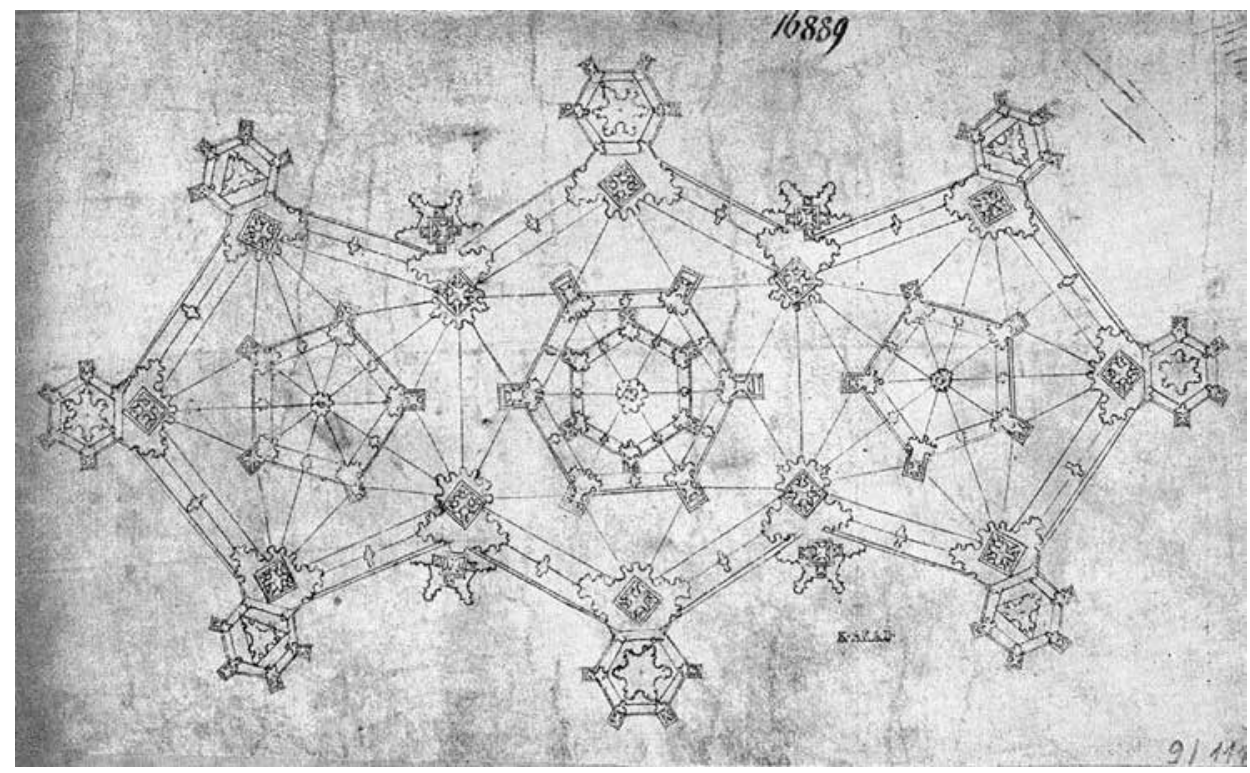

Figure 12. 'Fantastic plan' containing pentagons in the Collection of Prints and Drawings of the Vienna Academy of Fine Arts (after no. 16889, fig. 247 by Koepf 1969)

\footnotetext{
${ }^{74}$ In the frame of the current paper the certainly interesting but entirely rich examination of the use of the pentagon in military architecture is disregarded.

${ }^{75}$ Hoppe 1995. 166-167.

${ }^{76}$ Hoppe 1995. 169; Marosi 1987. 512, 517.
} 
used for the construction of a tower, we cannot connect it to any actual building activity of its time. Therefore a more precise identification of the goal of this drawing stays open. There are several comparable draftings in the Collection of Prints and Drawings of the Vienna Academy of Fine Arts, that represent pentagonal designs elaborated in a sophisticated manner. In the $15^{\text {th }}$-century sheets of $n o .16889,{ }^{77}$ no. $16994^{78}$ and no. $17002^{79}$ ideal plans can be identified using a pentagon. ${ }^{80}$ As Bucher has concluded from the lack of structural viability, these plans, especially no. 16889 could hardly be the design of constructions to be realized, he classified them as 'fantastic plans' ${ }^{81}$ (Fig. 12) On folio 103 of Master WG's book the late $16^{\text {th }}$-century cut-out figure $^{82}$ of a belike pentagonal space covered with a star vault can also be considered as a fantasy design.

\section{HALF-DECAGONAL APSES}

Among the possible forms of medieval apses of Catholic churches, polygonal ones represent a great percentage. Frequently they featured as five sides of the octagon, or they can be considered as a half hexagon, however, only accurate surveys could verify the real application of these figures during their geometrical design. As, except for some unique example, logically no pillars or angles are required in the main axe of the chevet, the generally semi-circular case of the apse is to be divided into odd parts, like five, seven or nine. These solutions have been quite frequently used, obviously depending on the era and the scale of the church. Although some examples of heptagonal and nonagonal apses also can be mentioned, ${ }^{83}$ pentagonal or more precisely half-decagonal ones have been much more frequent from the Early Christian period $^{84}$ to late Gothic times. Regarding the certainly obvious logic of this solution, it is no wonder that a high number of such choirs can be found. ${ }^{85}$ (Fig. 13) It is ques-

\footnotetext{
${ }^{77}$ Fig. 247 by Koepf 1969.

${ }^{78}$ Fig. 368 by Koepf 1969.

${ }^{79}$ Fig. 378 by Koepf 1969.

${ }^{80}$ Koepf 1969; Böker 2005. Also mentioned by Bucher 1976. 74.

${ }^{81}$ Bucher considered this drawing as a 'fantastic plan' defining type of design of the late Gothic. Bucher 1968. 69.

${ }^{82}$ Bucher 1979. 276.

${ }^{83}$ For instance in folio15 recto of the Sketchbook of Villard de Honnecourt there is the drawing of the chevet that was designed by Villard and Pierre de Corbe. Barnes 2009. 95. Furthermore the chevet of the Cistercian abbey of Notre-Dame of Vaucelles in folio 17 recto also can be mentioned. Barnes 2009. 106. Further example can be found in Master WG's lodge book. Bucher 1979. 337.

${ }^{84}$ Early examples: Deir Abu Fana (Quasr Hur) Coptic monastery, 6 ${ }^{\text {th }}$ century; Guzsik 1994. I. - Deir Abu Fana (Quasr Hur) Coptic monastery, $6^{\text {th }}$ century.

${ }^{85}$ Saint Bartholomew Church of Kolín, Saint Michael Cathedral of Alba Iulia, Saint Elisabeth of Košice, the Protestant Church of Miskolc-Avas after Plan Collection. - Furthermore Saint-Paul-Trois-Chateaux $\left(12-13^{\text {th }}\right.$ c.); Saint Restitut (12 $2^{\text {th }}$ c.); N.-D. of Dijon (13 ${ }^{\text {th }}$ c.); Albi $\left(13^{\text {th }}\right.$ c.) Cistercian abbey of Ourscamp (13 ${ }^{\text {th }}$ c.);
} 
tionable however, if all of these examples have been constructed with a quasi-regular pentagon or some alternative methods. Based on her measurements, Nancy Y. Wu has demonstrated the application of pentagons in the geometry of the chevet of Reims Cathedral, ${ }^{86}$ and so did Ellen M. Shortell in the case of the collegiate church of SaintQuentin. ${ }^{87}$ Otherwise, due to the lack of proper surveys, the reconstruction of the designs is rather vague. In some particular cases it is clear to determine that the hemicycle of the half-decagon is not regular: it is oval or its centre is out of the figure. ${ }^{88}$ However, by the experiences of the case study of Reims and Saint-Quentin, it can be suspiciously claimed that in most of the cases the design has been worked out with the application of some approximation of the pentagon drafting. Construction of semi-circular apses strengthened by semi-columns or pilasters dividing them into five parts could have followed a similar logic, thus certainly demanding the geometry of the pentagon. ${ }^{89}$ (Fig. 13) The wide chronological range of all the half-decagonal apses concludes that architects had to be aware of some kind of solution for constructing a pentagon from early to late Middle Ages.

Franciscan church of Salzburg (1408); Cathedral of Brügge (1480-1560); Cathedral of Brüssel (13 ${ }^{\text {th }}$ c.); Cathedral of Antwerp (14 ${ }^{\text {th }}$ century); after Christe et al. 1994. - And furthermore Cathedral of Carcassone $\left(13^{\text {th }}\right.$ c.); N.-D. of Tournai (1253); Cathedral of Ávila (12 ${ }^{\text {th }}$ c.); N.-D. of Trier (13 ${ }^{\text {th }}$ c.); Saint Elisabeth of Marburg (from 1235); Cathedral of Bordeaux (13-14 ${ }^{\text {th }}$ c.); N.-D. of Dinant (1227-1247); N.-D. of Avignon after Toman et al. 2000. - Further examples after Guzsik 1994: Saint Gotthard Church of Hildesheim, crypt (12 $2^{\text {th }}$ c.); both apses of the Cathedral of Bamberg $\left(12-13^{\text {th }}\right.$ c.); Cathedral of Basel $\left(12-13^{\text {th }}\right.$ c.); San Pietro in Ciel d'Oro, Augustinian church of Pavia (12 $2^{\text {th }}$ c.); N.-D. of Saumur $\left(12^{\text {th }}\right.$ c.); Santa Maria in Capitol church of Cologne $\left(11^{\text {th }}\right.$ c.); Saint Severin church of Cologne $\left(13^{\text {th }} \mathrm{c}\right.$.); Cathedral of Trier $\left(10^{\text {th }}\right.$ c. $)$; Saint Etienne Benedictine abbey of Nevers (11 ${ }^{\text {th }}$ c.); Saint Ours church of Lorches (11 th and $14^{\text {th }} \mathrm{c}$.); Cathedral of Tournai (12th c.); Saint Yved church of Braisne (13 ${ }^{\text {th }} \mathrm{c}$.); Cathedral of Narbonne (13 ${ }^{\text {th }} \mathrm{c}$.); Cathedral of Sées (13th c.); Cathedral of Burgos (13 ${ }^{\text {th }}$ c., reconstructed plan); Cathedral of Brandenburg $\left(13^{\text {th }}\right.$ c.); Cathedral of Stendal $\left(15^{\text {th }}\right.$ c. $)$; St. Maria zur Wiese church of Soest $\left(14^{\text {th }}\right.$ c.); Saint John church of Werben $\left(15\right.$ th c.); Cathedral of Utrecht $\left(14^{\text {th }}\right.$ c.); parish church of The Hague (15-16 $6^{\text {th }}$ c.); Saint Borbala church of Kutna Hora (14-16 ${ }^{\text {th }}$ c.); etc.

${ }^{86} \mathrm{Wu} 2002$.

${ }^{87}$ Shortell 2002.

${ }^{88}$ Some examples of non-regular apses of five sides: main church of Lazarica monastery in Krusevác (Serbie, 1380); main church of Ravenica monastery (Serbie, $4^{\text {th }} \mathrm{c}$.); Cathedral of Magdeburg (13-14 ${ }^{\text {th }}$ c.); Saint Moric and Catherine church in Magdeburg (13-14 $4^{\text {th }}$ c.); Saint Gabriel church of Tarascon (12 ${ }^{\text {th }}$ c.); Cathedral of Orange (12 $2^{\text {th }}$ c.); Cistercian abbey of Leoncel $\left(12^{\text {th }}\right.$ c.); Cistercian abbey of Val-Dieu (12 ${ }^{\text {th }}$ c.); San Francesco church of Assisi (13 ${ }^{\text {th }}$ c.); parish church of Breda (15 $5^{\text {th }}$ c.); etc. after Guzsik 1994.

${ }^{89}$ Examples of semi-circular apses divided into five parts: Saint-Cybard church of Blanzagouet $\left(12^{\text {th }} \mathrm{c}\right.$.) after George 1933. 39; Cathedral of Angers (1148-1153) after Altet 1987 and Christe et al. 1994. - Church of Sanvignes $\left(12^{\text {th }}\right.$ century) after Daragó 2015; Cathedral of Noyons (1185); N.-D. of Paris $\left(12^{\text {th }}\right.$ c.); Cathedral of Troyes $\left(13^{\text {th }}\right.$ c.); Cathedral of Toledo $\left(13^{\text {th }}\right.$ c.) after Christe et al. 1994. - Cathedral of Reims; Sain Rémy of Reims (11-12 ${ }^{\text {th }}$ century); Cathedral of Saint Quentin (13 ${ }^{\text {th }}$ century); Abbey of Maria Laach; Saint-Germain-desPrès in Paris (1163); Cathedral of Bourges $\left(12-13^{\text {th }}\right.$ c.) after Toman et al. 2000. - Further examples after Guzsik 1994: Sergiuopolis mausoleum in Ruszafah (central semi-circular arcades divided into five parts, $6^{\text {th }} \mathrm{c}$.), Magalé Panagia, Syria $\left(9-10^{\text {th }} \mathrm{c}\right.$ ), baptistery in Venasque (from the $\left.6^{\text {th }} \mathrm{c}.\right)$. - Cathedral of Norwich $\left(11-12^{\text {th }} \mathrm{c}\right.$.); Cathedral of Ely (1 $11^{\text {th }}$ c.); Saint Frons of Périgueux; Saint Marie-Madeleine of Vézelay; Saint-Martin-d'Ainay of Lyon; Cathedral of Vaison-la-Romain; etc. 


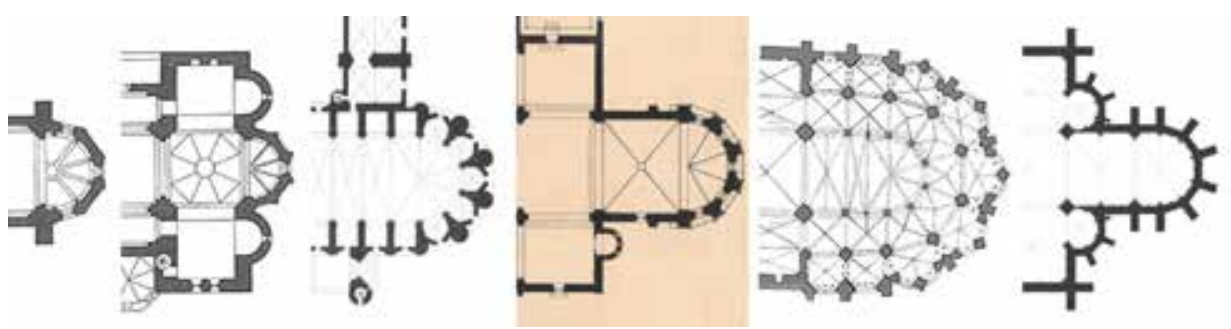

Figure 13. Some examples of quasi-regular half-decagonal apses and semi-circular apses divided to five parts: church of Saint Restitut, church of Saint-Paul-Trois-Chateau, Cathedral of Albi, San Zeno of Verona, Saint Marie-Madeleine of Vézelay, Notre-Dame of Dijon (Christe et al. 1994; Wiener Bauhütte J IV. S II. no. 1; Archéologie 2010)

The clearness of their geometrical logic, for instance, is entirely visible in Villard de Honnecourt's folio 15 recto, in his drawing of the chevet of the Cathedral of Meaux with the description 'vesci les ligement de le glize de miax de saint estienne'. ${ }^{90}$ (Fig. 14) While this drawing, as Peter Kurmann has demonstrated, ${ }^{91}$ is certainly a sketch, Villard has elaborated it in a rather sophisticated manner using a compass which is testified by the presence of pinpricks. ${ }^{92} \mathrm{~A}$ less detailed but certainly significant sketch of a half-decagonal choir can be found in the Collection of Prints and Drawings of the Vienna Academy of Fine Arts in sheet no. $16912 .{ }^{93}$ In this case the correct drafting or the use of any pentagon approximations are quite questionable, but the appearance of the solution as a 'fantastic' plan of the Vienna collection shows
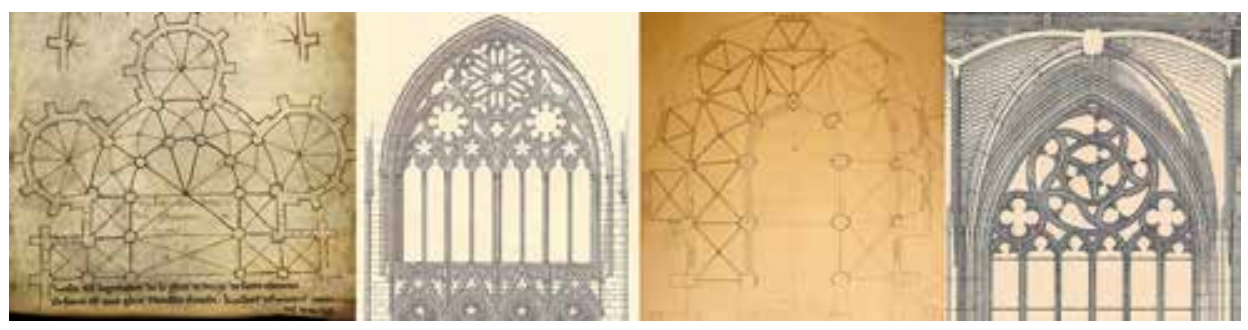

Figure 14. Some example of churches with pentagon both in the plan of the choir and tracery compositions: the choir of Saint Etienne of Meaux by Villard de Honnecourt (after folio $15 r$ in Barnes 2009) and details of the tracery windows of the Northern transept; choir of Saint Bartholomew Church of Kolín, Czech Republic (Plan Collection no. 104036) and tracery window (Wiener Bauhütte J III. S II. no. 48)

${ }^{90}$ 'See here the plan of the church of Saint Etienne at Meaux' translated by Barnes 2009. 96.

${ }^{91}$ Kurmann 1967. 8.

${ }^{92}$ Barnes 2009. 96-97. Further half decagonal apse can be found in folio 14 verso: the chevet of Saint Mary of Cambrai. Barnes 2009. 92.

${ }^{93}$ Fig. 278 by Koepf 1969. 
its importance. The regularity of the decagon could also be doubted like in the case of two cut-out figures of Master WG, who also experimented with this type of apses. ${ }^{94}$

\section{PENTAGONAL TRACERY WINDOWS}

In the case of the many pentagonal tracery works the purpose of choosing this geometrical figure was different compared to apses or rotundas. While the former represents a mainly ornamental detail, the shape determines the space or the mass of the building in the latter. While an ornamental element is didactic, the form of the plan may not be obvious at once. Being explicitly visible, tracery windows served the decoration and especially with colored stained glass the symbolic program of Gothic building in a didactic way.

Even though in tracery compositions the use of the triangle, the square, the hexagon or the octagon (or three-, four-, six- and eight-foiled figures) is far more frequent, the number of pentagonal examples exceeds the expectations. Moreover, it is remarkable that in several buildings pentagonal, construction appeared multiply. Both the apse form and the tracery works contain pentagon, for instance in the case of Saint Gereon Church of Cologne, ${ }^{95}$ Saint Bartholomew of Kolín (Czech Republic) ${ }^{96}$ Notre Dame of Paris ${ }^{97}$ the Cathedral of Meaux ${ }^{98}$ Saint Vitus Cathedral of Prague, ${ }^{99}$ the Cathedral of Soissons, ${ }^{100}$ the Cathedral of Bordeaux, etc. (Fig. 14) Aside from the decagonal choir, tracery also demanded the knowledge of some kind of pentagon construction. A rich collection of further examples can be mentioned, which proves its general application. ${ }^{101}$ (Fig. 15) While the pentagon tends to appear in several forms in one church construction, it is also quite general that a pentagon or a decagon

${ }^{94}$ Folio 223-224 and 275-276. Bucher 1979. 336, 362.

${ }^{95}$ In the $14^{\text {th }}$-century sacristy, after Wiener Bauhütte J III. S II. no. 17.

${ }^{96}$ Wiener Bauhütte J III. S II. no. 48.

${ }^{97}$ Windows of the Western façade of the Northern transept, and next to them windows of both sides of the nave $(1250 \mathrm{k}$.$) , etc.$

${ }^{98}$ In the great tracery window of both transepts.

${ }^{99}$ The western rose window and windows of lateral façades.

${ }^{100}$ Blind tracery in the Eastern portail of the Northern transept.

${ }^{101}$ In the Cathedral of Evreux the windows of the heptagonal chevet contain pentagonal traceries and the great rose window of both transepts are decagonal. (13-14 th c.) Toman et al. 2000. - Further examples: Cathedral of Cologne (southern façade windows) after Guzsik 1994.III.; Saint Katherine Church of Oppenheim am Rhein (window of the Southern façade of the nave $\left(14^{\text {th }} \mathrm{c}\right.$.) and Saint Wolfgang in Gnadlersdorf in Mahren (round windows above the portails of the nave, after Wiener Bauhütte vol. XXIII. - Cathedral of Münster (the curious upper rose window of the Southern transept gable, after Wiener Bauhütte J VIII. S II. no. 9; the sanctuary of the abbey and the cloister of Heiligenkreuz after Toman et al. 2000 and Wiener Bauhütte J VI. S II. no. 31. - Cathedral of Wetzlar and Cathedral of Exeter (the Western window); N.-D. and Saint Sebald Church of Nürnberg after Toman et al. 2000. - Cathedral of Lincoln; N.-D. of Gelnhausen (1220-1240); N.-D. of Worms $\left(14^{\text {th }}\right.$ c.); Bischop's Palace in Sens (1240); Saint George Church of Sélestat (15 ${ }^{\text {th }}$ c.) after Christe et. al. 1994. - Cathedral of Regensburg, Cathedral of Rouen, etc. 


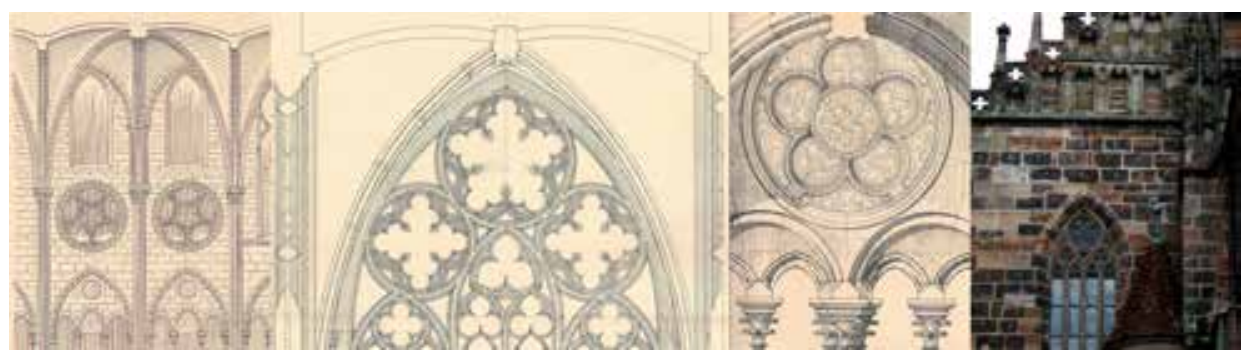

Figure 15. Some examples of pentagonal tracery windows: Notre Dame of Paris (after Christe et al. 1994. 309); Saint Gereon Church of Cologne (Wiener Bauhütte J III. S II. no. 17); the cloister of Heiligenkreuz (Wiener Bauhütte J IV. S II. no. 31); Notre-Dame of Nürnberg (authors' photo)

can be found in various buildings in one particular town. In Münster, for instance, both the cathedral (chevet and a detail of the rose window in the gable of the Southern transept) and the façade of the $14^{\text {th }}$-century town hall contain pentagons. ${ }^{102}$ In Vianden (Luxembourg), beside the above mentioned castle chapel, the northern window of the Saint Nicolas Church could have demanded some kind of geometrical pentagon construction.

Concerning the medieval Kingdom of Hungary, Sedlmayr has drawn the attention to a window of the Northern façade of Saint Michael Church of Sopron probably from the $14^{\text {th }}$ century, ${ }^{103}$ a tracery window from the Saint Jacob Church of Levoča (Löcse) $)^{104}$ and the rural example of the Northern round window of the Roman Catholic Church of Mátraverebély from about $1400 .{ }^{105}$ (Fig. 16) The pentagonal blind-tracery work above the choir-stalls of the church of Szászfenes (Florești, Romania) can prove, however, that in some cases, especially in rural areas, the tracing of the pentagon was worked out without any geometrical construction. It is also worth to note that in Sopron another formerly ruined pentagonal tracery composition has been reconstructed in the chapter house of the Franciscan Church by the notable Hungarian sculptor Ernö Szakáll. ${ }^{106}$ (Fig. 16) Beside these traceries from the flourishing centuries of Gothic, some unique examples also can be cited such as the early five-foiled windows on the Southern transept of Santiago de Compostela from the $12^{\text {th }}$ century ${ }^{107}$ or the $16^{\text {th }}$-century survival of Gothic windows in Quito Cathedral of Ecuador in South America. Notwithstanding that our paper has confined itself to the examination of the Middle Ages, the problematic of the geometrical construction and architectural application of the pentagon is of high relevance in later historical periods as well.

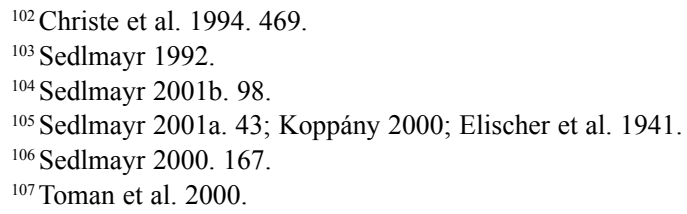



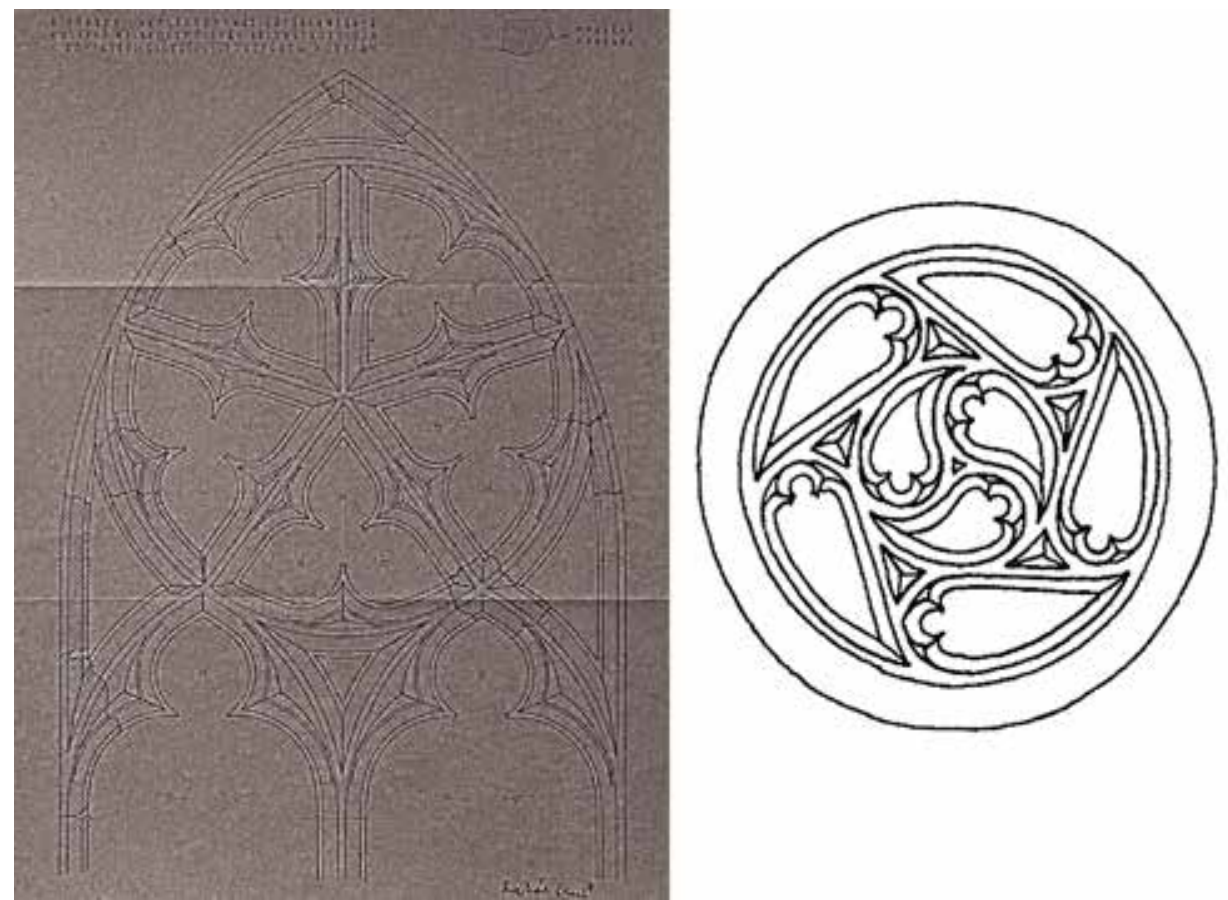

Figure 16. Reconstruction of the tracery window of the Franciscan chapter house in Sopron by Erno" Szakáll (Plan Collection no. 105406) and the Northern round window of the Roman Catholic Church of Mátraverebély (after Elischer et al. 1941. 1)

\section{CONCLUSION}

The deeper analysis of the pentagonal drawings in Gothic sources and the collection of architectural examples for the pentagon stimulate the rethinking of the consideration of its role in medieval architecture. Sedlmayr and Hoppe shared the opinion that the pentagon was a figure rarely used in design because of its unfamiliar geometrical construction and translation to the site, and if it was after all applied, it must have served the representation of the master's virtuosity in mathematical knowledge. ${ }^{108}$ While appreciating this argument, the question can be reconsidered, as it is likely that the pentagon was not as peripheral as it had been estimated before. The appearance of standalone central buildings with a plan of an ideal or quasi-regular pentagon or decagon is definitely scarce both in the early and late Middle Ages. In these cases, compared to other polygons, especially square, hexagon and octagon, odd sided polygons are likely to have been used for special reasons, for instance the

${ }^{108}$ Hoppe 1995; Sedlmayr 1992. 
symbolic meaning of numbers, as it is presumable in the case of centrally planned spaces. In the construction of the half decagonal apses the odd sided division of the semicircle is quite logical, so the reason is more likely to be functional or structural. The rather frequent examples of these constructions as well as tracery windows suggest that master masons of all centuries of the Middle Ages had known some methods for the drafting of the figure. This suggestion seems more reasonable regarding the different kinds of geometrical approximations appearing in medieval sources associated with the several simple solutions using, for instance, numerical proportions for producing the pentagon. Anyhow, these methods stay speculative until any evidences of their practical use can be pointed out in the Middle Ages. Their simplicity suggests, however, that they may have been known, transferred or figured out by medieval architects, thus the construction of a pentagon had likely been part of the mathematical background knowledge of master masons.

\section{ACKNOWLEDGEMENT}

\section{岛 \\ SupPorted by the ÚNKP-17-3-I New National Excellence Program of the Ministry of Human Capacities.}

\section{BIBLIOGRAPHY}

Altet 1987

Barnes 2009

Bechmann 1991

Bondurand 1887

Borwein et al. 1997

Böker 2005

Bucher 1968

Bucher 1976
Altet, Xavier Barral I (dir.): Le Paysage Monumental de la France autour de l'an mil. Colloque International C.N.R.S. Picard, Paris 1987.

Barnes, Carl F.: The Portfolio of Villard de Honnecourt. A New Critical Edition and Color Facsimile. Ashgate, 2009.

Bechmann, Robert: Villard de Honnecourt. La pensée technique au XIIIe siècle et sa communication. Picard, Paris 1991.

Bondurand, Édouard (ed. and tr.): Le Manuel de Dhuoda. Picard, Paris 1887.

Borwein, Jonathan - Borwein, Peter - Berggren, J. L.: A Source Book. Springer, 1997.

Böker, Johann Josef: Architektur der Gotik. Bestandskatalog der weltgrößten Sammlung an gotischen Baurissen (Legat Franz Jäger) im Kupferstichkabinett der Akademie der Bildenden Künste Wien; mit einem Anhang über die mittelalterlichen Bauzeichnungen im Wien Museum am Karlsplatz. Anton Pustet, Salzburg 2005.

Bucher, François: Design in Gothic Architecture: A Preliminary Assessment. Journal of the Society of Architectural Historians 27 (1968) 1. 49-71. DOI: $10.2307 / 988429$

Bucher, François: Micro-Architecture as the 'Idea' of Gothic Theory and Style. Gesta. Essays in Honor of Sumner McKnight Crosby 15 (1976) 1-2. 71-89. 
Bucher 1979

Christe et al. 1994

Daragó 2015

Devlin 2012

George 1933

Elischer et al. 1941

Entz 1992

Fehér et el. 2018

Fuchs 1992

Gervers-Molnár 1972

Gil-López 2012

Goonatilake 1998

Guzsik 1994

Gyöngyössy 1995

Hahnloser 1972

Hiscock 2000

Hoppe 1995

de Jonge 2014

Koepf 1969

Koppány 2000

Kurmann 1967

Marosi 1987

Meckseper 1983
Bucher, François: Architector. The Lodge Books and Sketchbooks of Medieval Architects. Volume 1. Arabis Books, New York 1979.

Christe, Yves - Losowska, Hanna - Recht, Roland - Velmans, Tania: Formen und Stile. Christentum. Taschen, Cologne 1994. ISBN 3-82288967-9

Daragó, László: Romanesque Churches in Burgundy. Heritage Surveys at the BME Department of History of Architecture and of Monuments 20082014. Budapest 2015.

Devlin, Keith: The Man of Numbers: Fibonacci's Arithmetic Revolution. Walker Books 2012. ISBN 978-0802779083

George, Jean : Les églises de France. Charente. Letouzey et Ané, Paris 1933.

Elischer, Gyula - Csányi, Károly - Lux, Géza: A mátraverebélyi róm. kat. plébánia-templom. Technika 12 (1941) 5.

Entz, Géza: Le séjour en Hongrie de Hans Hammer, futur maître d'œuvre de la cathédrale de Strasbourg. Bulletin de la Cathédrale de Strasbourg 20 (1992) 7-10.

Fehér, Krisztina - Szilágyi, Brigitta - Halmos, Balázs: Golden Ratio and Fibonacci Sequence in Pentagonal Constructions of Medieval Architecture. YBL Journal of Built Environment 6 (2018).

Fuchs, François Joseph: Introduction au «Musterbuch» de Hans Hammer. Bulletin de la Cathédrale de Strasbourg 20 (1992) 11-70.

Gervers-Molnár Vera: A középkori Magyarország rotundái. Akadémiai Kiadó, Budapest 1972.

Gil-López, Tomás: The Vault of the Chapel of the Presentation in Burgos Cathedral: "Divine Canon? No, Cordovan Proportion" Nexus Network Journal 14 (2012) 1. 177-189.

Goonatilake, Susantha: Toward a Global Science. Indiana University Press, 1998. ISBN 978-0-253-33388-9

Guzsik Tamás: Középkori épitészettörténeti ábraanyag, I. II. III. Budapesti Müszaki Egyetem Építészettörténeti és Elméleti Intézet, Budapest 1994. Gyöngyössy János: Székelyföldi vártemplomok. Budapest 1995.

Hahnloser, Hans R.: Villard de Honnecourt: kritische Gesamtausgabe des Bauhüttenbuches. Akademische Druck und Verlagsanstalt, Graz 1972.

Hiscock, Nigel: The Wise Master Builder. Platonic Geometry in Plans of Medieval Abbeys and Cathedrals. Ashgate, 2000.

Hoppe László: Az ötszög szerkesztése a középkorban: Hans Hammer ötszögszerkesztése. Épités- Épitészettudomány 25 (1995) 1-2. 139-171.

de Jonge, Krista: Early Modern Netherlandish Artist on Proportion in Architecture, or 'de questien der Simmetrien met redene der Geometrien'. Architectural Histories 2 (2014) 11. 1-23.

Koepf, Hans: Die gotischen Planrisse der wiener Sammlungen. Hermann Böhlaus Nachf, Vienna, Cologne, Graz 1969.

Koppány Tibor: Mátraverebély. Római katolikus templom. (Tájak, korok, múzeumok kiskönyvtára 665.) Budapest 2000.

Kurmann, Peter: Saint-Etienne de Meaux d'après Villard de Honnecourt. Bulletin de la société littéraire et historique de la Brie 24 (1967) 5-23.

Marosi Ernő: Magyarországi müvészet 1330-1470 körül. Volume I. Akadémiai Kiadó, Budapest 1987.

Meckseper, Cord: Über die Fünfeckkonstruktion bei Villard de Honnecourt und im späteren Mittelalter. Architectura 13 (1983) 31-40. 
Nagy 2002

Scriba et al. 2015

Sedlmayr 1992

Sedlmayr 2000

Sedlmayr 2001a

Sedlmayr 2001b

Shalby 1977

Shortell 2002

Sódor 1978a

Sódor 1978b

Sódor 1981

Sódor 1982

Spiess 1959

Toman et al. 2000

Wu 2002

Archéologie 2010

Plan Collection
Nagy, Mihály: Typological Considerations on Christian Funerary Buildings in Pannonia. Zalai Múzeum 11 (2002) 7-30.

Scriba, J. C. - Schreiber, P.: 5000 Years of Geometry. Mathematics in History and Culture. Birkhäuser, 2015. ISBN 978-3-0348-0897-2

Sedlmayr János: Két különleges mérmủves ablak a soproni Szent Mihálytemplomon. Müemlékvédelem 36 (1992) 1. 17-22.

Sedlmayr János: Anjou-kori magyarországi mérmüvek. Müemlékvédelem 44 (2000) 3. 163-170.

Sedlmayr János: Magyarországi érett gótikus mérművek (1380-1460). Müemlékvédelem 45 (2001) 1. 38-43.

Sedlmayr János: Magyarországi késő gótikus mérműves ablakok. Müemlékvédelem 45 (2001) 2. 96-102.

Shalby, Lon R.: Gothic Design Techniques: The Fifteenth-Century Design Booklets of Mathes Roriczer and Hanns Schmuttermayer. Southern Illinois University Press, 1977.

Shortell, Ellen M.: The Plan of Saint-Quentin: Pentagon and Sqare in the Genesis of High Gothic Design. In: Ad Quadratum. The Practical Application of Geometry in Medieval Architecture. Ed.: Wu, Nancy Y. Ashgate, 2002. 123-148.

Sódor Alajos: Az épitészeti tervezés alaptendenciái a középkorban. Egyetemi jegyzet, Müszaki Egyetem Építésztetörténeti és Elméleti Intézet Mủemléki Osztály, Budapest 1978.

Sódor Alajos: Matthes Roriczer 1496-ban megjelent fiatorony könyve. Épités- Épitészettudomány 10 (1978) 3-4. 381-421.

Sódor Alajos: Hans Schmuttermayer kései középkori fiatorony könyve. Épités- Épitészettudomány 13 (1981) 1-2. 193-209.

Sódor Alajos: Matthes Roriczer „Geometria Deutsch”és, Wimpergbüchlein” című könyveiröl (1486-1490). Épités- Épitészettudomány 14 (1982) 3-4. 373-405.

Spiess, Herwig: Mass und Regel. Eine mittelalterlische Messordnung an romanischen Bauten in Kloster Eberbach. Dissertation. Aachen 1959. 3036.

Toman, Rolf - Beyer, Brigit - Borngässer, Barbara (eds): Gótikus stílus. Épitészet, szobrászat, festészet. Vince, Budapest 2000.

Wu, Nancy Y.: The Hand of the Mind: The Ground Plan of Reims as a Case Study. In: Ad Quadratum. The Practical Application of Geometry in Medieval Architecture. Ed.: Wu, Nancy Y. Ashgate, 2002. 149-168.

Archéologie en Bourgogne. DRAC Bourgogne, Dijon 2010. ISSN 17716640

Plan Collection and Archives of the BME Department for History of Architecture and of Monuments 


\section{ÖTSZÖGEK A KÖZÉPKORI ÉPÍTÉSZETBEN}

\section{Összefoglaló}

Bonyolult geometriai szerkesztése és páratlan oldalainak köszönhető bizonytalan térhatása miatt a szabályos ötszög építészeti megjelenését ritkának tartják. A keresztény szimbolikában az ötszög és az ötös szám gazdag jelentéstartalommal bír. Habár a szabályos szerkesztést már az ókorban ismerték, semmi jel nem utal arra, hogy ezt a tudást a középkori építészek is használták. A korabeli források csupán közelítö módszereket ismertetnek. A középkorban az ötszög többek között olyan építészeti elemeken van jelen, mint a mérművek, toronyalaprajzok és szentélyek. Ellentétben az eddigi elképzeléssel, amely szerint ezt a formát összetett szerkesztése miatt ritkán használták, számos példa mutatja, hogy alkalmazása valójában meglehetősen általánosnak mondható. Tanulmányunk áttekintést nyújt a középkori építőmesterek által használt lehetséges ötszögszerkesztö-módszerekről és a forma alkalmazásának módjairól.

Kulcsszavak: ötszög, középkor, építészet, gótika, geometria, matematika 